\title{
Engrailed-2 promoter hyper-methylation is associated with its downregulation in clear cell renal cell carcinoma
}

\author{
CAI-YONG LAI ${ }^{1,2^{*}}$, GAN-SHEN YU ${ }^{1 *}$, YIN XU ${ }^{1}$, XUN WU ${ }^{1}$, BAO-LI HENG ${ }^{1}$, YI-JUN XUE ${ }^{2}$ and ZE-XUAN SU ${ }^{1}$ \\ ${ }^{1}$ Department of Urology, The First Affiliated Hospital of Jinan University, Guangzhou, Guangdong 510632; \\ ${ }^{2}$ Department of Urology, The First Affiliated Hospital of Gannan Medical College, Ganzhou, Jiangxi 341000, P.R. China
}

Received June 6, 2016; Accepted July 27, 2017

DOI: $10.3892 / 01.2017 .7000$

\begin{abstract}
In a previous study by the present authors, it was identified that the expression of engrailed-2 (EN2) gene was downregulated in clear cell renal cell carcinoma (cc-RCC). The aim of the present study was to determine whether aberrant methylation was the mechanism underlying the silencing of EN2 gene in cc-RCC. A total of forty paired cc-RCC tissues, four cc-RCC cell lines and one normal human proximal tubule epithelial cell line were evaluated for EN2 gene methylation status using methylation-specific polymerase chain reaction (PCR). Following treatment with 5-Aza-dc, reverse transcription-quantitative PCR and western blot analysis were performed to examine the expression of EN2. Furthermore, cell proliferation, apoptosis and invasion assays were conducted to analyze the inhibitory effects of EN2 re-expression in 786-O cells. The results of the present study demonstrated that hyper-methylation of EN2 was identified in 12/40 cc-RCC tissues and all cc-RCC cell lines. The methylation status of the EN2 gene was revealed to be associated with histological grade and tumor size in cc-RCC. Following 5-Aza-dc treatment, demethylation of the EN2 gene was identified in 786-O cells, in conjunction with EN2 re-expression. Furthermore, re-activation of the EN2 gene markedly inhibited the proliferative and invasive capacities of cc-RCC. The results of the present study demonstrated that the EN2 gene promoter was hyper-methylated in cc-RCC, which may underlie the silencing of the EN2 gene in cc-RCC.
\end{abstract}

Correspondence to: Professor Ze-Xuan Su, Department of Urology, The First Affiliated Hospital of Jinan University, 613 Huang Pu Road, Guangzhou, Guangdong 510632, P.R. China E-mail: zexuansu2014@126.com

*Contributed equally

Key words: engrailed-2, clear cell renal cell carcinoma, DNA methylation

\section{Introduction}

Renal cell carcinoma (RCC) is one of the most common types of adult malignancies, accounting for $>61,000$ new cases and $>14,000$ mortalities each year (1). Clear cell renal cell carcinoma (cc-RCC), which originates from the renal proximal tubule, is the most common histological subtype of RCC (2). cc-RCC accounts for $80-90 \%$ all RCC cases (2). Extensive efforts have been made to investigate the pathogenesis of cc-RCC and have led to important insights into the biology of the disease. However, there is a lack of effective treatment for patients with advanced cc-RCC. Patients with cc-RCC may exhibit no clinical symptoms in the early stage, and 20-30\% of cases are initially diagnosed at the advanced stage (3). Despite the development of targeted therapies, the mortality rate of patients with advanced cc-RCC remains high (4). Surgical resection remains the principal therapeutic method for localized cc-RCC and early diagnosis of localized cc-RCC is associated with a favorable outcome (5).

Engrailed-2 (EN2) is one member of the homeobox (HOX) gene family and has an important function in the development of the nervous system at the embryonic stage (6). Previous studies have demonstrated that the EN2 gene is highly expressed in a number of types of malignant tumor, including prostate (7), breast (8) and bladder (9) cancer. However, a previous study by the present authors revealed that the expression of EN2 gene was relatively decreased in cc-RCC tissues compared with normal kidney tissue (10). A previous study demonstrated that the level of EN2 mRNA in cc-RCC was negatively associated with tumor differentiation (10). Therefore, one of the main aims of the present study was to investigate the reasons underlying why the EN2 gene is downregulated in c-RCC.

Numerous studies (11-14) have demonstrated that aberrant DNA methylation, a typical epigenetic modification, serves an important function in the tumor suppressor genes inactivated. The present study hypothesized that promoter DNA methylation may be the mechanism that leads to the downregulation of the EN2 gene in cc-RCC. Therefore, the present study analyzed the promoter methylation status of the EN2 gene using the methylation-specific polymerase chain reaction (MSP). Following demethylation, performed using the DNA methyltransferase inhibitor 5-Aza-dc, alterations in the status of promoter methylation and the level of EN2 expression were 
analyzed. Furthermore, the effects of the re-activation of EN2 on cell proliferation, apoptosis and invasion were analyzed.

\section{Materials and methods}

Cell lines and cell culture. A total of three human cc-RCC cell lines (786-O, ACHN and A498) and one normal human proximal tubule epithelial cell line (HK-2) were obtained from the Cell Bank of Type Culture Collection of Chinese Academy of Sciences (Shanghai, China). HK-2 cells were cultured in Dulbecco's modified Eagle's medium/F12 medium (Invitrogen; Thermo Fisher Scientific, Inc., Waltham, MA, USA). The three tumor cell lines were cultured in RPMI 1640 medium (Invitrogen; Thermo Fisher Scientific, Inc.). All medium was supplemented with $10 \%$ fetal bovine serum (Gibco; Thermo Fisher Scientific, Inc.) and $1 \%$ penicillin-streptomycin solution (Gibco; Thermo Fisher Scientific, Inc.). All cell lines were incubated in a humidified atmosphere containing $5 \% \mathrm{CO}_{2}$ at $37^{\circ} \mathrm{C}$.

Tissue samples. A total of 40 pairs of tumor tissues and matched adjacent non-malignant tissues were obtained from patients with cc-RCC, who underwent radical or partial nephrectomy at the First Affiliated Hospital of Jinan University (Guangzhou, China) between January 2007 and August 2015. The average age of the patients was 54.5 years. All patients with cc-RCC were diagnosed by pathological examination. None of the patients had undergone chemotherapy or radiotherapy prior to surgery. The clinicopathological features of these enrolled patients was classified according to the 1997 TNM system (15) and the General Rules for Clinical and Pathological Studies on Renal Cell Carcinoma of the Japanese Urological Association, 3rd edition, 1999 (16). The present study was approved by the Institutional Review Board of Jinan University, and each patient signed informed consent.

DNA methyltransferase inhibitor (5-aza-2-deoxycytidine/5-A $z a-d c)$ treatment. The cc-RCC cell line 786-O was incubated at $37^{\circ} \mathrm{C}$ with various concentrations of 5-Aza-dc $(0,2.5,5$, 10 and $20 \mu \mathrm{mol} / \mathrm{l}$; Sigma-Aldrich; Merck KGaA, Darmstadt, Germany) for 5 days. Following incubation, changes in EN2 gene promoter methylation and the restoration of EN2 gene expression were analyzed.

DNA extraction and methylation-specific PCR (MSP). Genomic DNA from cell lines and tissue specimens was extracted using a standard treatment of digestion with SDS/proteinase K solution, followed by phenol-chloroform extraction and ethanol precipitation. Subsequently, bisulfite modification of genomic DNA was performed using the EZ DNA Methylation-Gold kit (Zymo Research Corp., Irvine, CA, USA) according to the manufacturer's protocol. The total PCR reaction $(25 \mu \mathrm{l})$ consisted of: $0.5 \mathrm{mM}$ primers, $2.5 \mathrm{mM}$ dNTPs, $1 \mathrm{X}$ buffer, $2 \mu \mathrm{l}$ bisulfite-treated DNA and $0.25 \mu \mathrm{l}(5 \mathrm{U} / \mu \mathrm{l})$ TaqTM HS (Takara Biotechnology Co., Ltd., Dalian, China). Methylation-specific PCR amplification was performed for 5 min initial denaturation at $95^{\circ} \mathrm{C}$, followed by 35 cycles of $94^{\circ} \mathrm{C}$ for $30 \mathrm{sec}, 60^{\circ} \mathrm{C}$ for $40 \mathrm{sec}, 72^{\circ} \mathrm{C}$ for $30 \mathrm{sec}$ and $72^{\circ} \mathrm{C}$ extension for $10 \mathrm{~min}$. MSP analysis was performed for EN2 using primers specific for methylated and unmethylated DNA products. The primer sequences are as follows: Methylated DNA product: Forward, 5'-AACGCGTTGTTTGTATGC-3'; and reverse, 5'-AAACAATCGCAATAATCCG-3' (product size, $138 \mathrm{bp}$ ) and unmethylated DNA product forward, 5'-GGG AATGTGTTGTTTGTATGT-3' and reverse 5'-AAACAATCA CAATAATCCAACA-3' (product size, 138 bp). For each set of DNA modification and PCR, normal human lymphocyte DNA was used as an unmethylated positive control. The lymphocyte DNA that had been methylated by SssI methylase served as a methylated positive control. Distilled water without DNA served as a control for contamination. PCR products were separated and analyzed using a 3\% agarose gel with appropriate size markers.

RNA extraction and reverse transcription-quantitative $(R T-q P C R)$. The 786-O cells were harvested using centrifugation $(300 \mathrm{x} \mathrm{g})$ at $37^{\circ} \mathrm{C}$ for $5 \mathrm{~min}$, following 5-Aza-dc treatment. The total RNA was extracted and reverse transcribed into cDNA as described previously (10). qPCR was performed using the Applied Biosystems 7500 Fast Real-Time PCR System (Applied Biosystems; Thermo Fisher Scientific, Inc.). The reaction mixture contained $5 \mu \mathrm{l}$ cDNA, $0.5 \mathrm{mM}$ primer, $10 \mu 12 X$ SYBR Green PCR SuperMix (Invitrogen; Thermo Fisher Scientific, Inc.) and $4 \mu \mathrm{l} \mathrm{dH}_{2} \mathrm{O}$. The mRNA expression of EN2 gene was determined using qPCR using the following protocol: $50^{\circ} \mathrm{C}$ for $2 \mathrm{~min}, 95^{\circ} \mathrm{C}$ for $2 \mathrm{~min}$, followed by 40 cycles of $95^{\circ} \mathrm{C}$ for $15 \mathrm{sec}$ and $60^{\circ} \mathrm{C}$ for $32 \mathrm{sec} .18 \mathrm{~S} \mathrm{rRNA}$ was selected as a reference and internal control. The sequences of the primers are as follows: EN2 forward, 5'-AGAAGAACCCGAACA AAGAG-3'; reverse, 5'-GTACCTGTTGGTCTGGAACTC-3'; 18S ribosomal (r)RNA forward, 5'-CCTGGATACCGCAGC TAGGA-3' and reverse, 5'-GCGGCGCAATACGAATGC CCC-3'. The primers were synthesized by Sangon Biotech Co., Ltd. (Shanghai, China). The relative mRNA expression of EN2 gene was calculated using the $2^{-\Delta \Delta \mathrm{Cq}}$ method (17).

Protein isolation and western blotting. Following 5-Aza-dc treatment, the 786-O cells were submitted to western blot assay as described previously (10). Briefly, total protein was extracted from cells using radioimmunoprecipitation assay buffer (BestBio, Shanghai, China). The protein content was quantified using the BCA Protein Assay kit (BestBio) according to the manufacturer's protocol. Western blot analysis was performed using $60 \mu \mathrm{g}$ of protein lysate isolated from the cells. Subsequently, proteins were separated using $10 \%$ SDS-PAGE and transferred to polyvinylidene difluoride membranes (Merck KGaA). The membranes were blocked using 5\% bovine serum albumin (Beijing Dingguo Changsheng Biotechnology Co., Ltd., Beijing, China) in Tris-Buffered Saline with Tween-20 and incubated with a rabbit polyclonal anti-EN2 antibody at a dilution of 1:1,000 (Abcam, Cambridge, UK; cat. no., ab28731) overnight at $4^{\circ} \mathrm{C}$, or a rabbit monoclonal anti-GAPDH antibody (cat. no., BM3875; Wuhan Boster Biological Technology, Wuhan, China) at a dilution of 1:3,000 overnight at $4^{\circ} \mathrm{C}$. Subsequently, the membranes were incubated with horseradish peroxidase-conjugated secondary antibodies (dilution, 1:2,000; Wuhan Boster Biological Technology; cat. no., BA1054) at room temperature for $1 \mathrm{~h} 30 \mathrm{~min}$. Finally, the membranes were visualized using an enhanced chemiluminescence detection kit (BestBio). 
Cell proliferation assay and apoptosis assay. Cell proliferation was determined using MTT colorimetric assay. The 786-O cells were seeded in 96 -well plates $\left(5 \times 10^{3}\right.$ cells/well) and incubated in RPMI 1640 medium containing various concentrations of 5-Aza-dc $(0,2.5,5,10$ and $20 \mu \mathrm{mol} / \mathrm{l})$ at $37^{\circ} \mathrm{C}$ for $1,2,3$ and 5 days. Subsequently, $20 \mu 1$ MTT $(5 \mathrm{mg} / \mathrm{ml}$; Sigma-Aldrich; Merck KGaA) was added to each well, and the cells were incubated at $37^{\circ} \mathrm{C}$ for $4 \mathrm{~h}$. Subsequently, the MTT-containing medium was removed and replaced with $100 \mu$ l dimethyl sulfoxide to dissolve the formazan crystals. Absorbance was measured at $570 \mathrm{~nm}$ using a microplate reader. Following the deduction of the blank cell absorbance, the cell proliferation rate $(\%)$ was calculated using the following formula: Cell proliferation rate $(\%)=$ [optical density $(\mathrm{OD})$ value of treatment / OD value of control] x 100.

Following treatment with 5-Aza-dc for 5 days, apoptotic cells were quantified using the Annexin V-FITC Apoptosis Detection kit (Nanjing KeyGen Biotech Co., Ltd., Nanjing, China) according to the manufacturer's protocol. The cells were analyzed using a FACS Calibur flow cytometer (BD, Biosciences, Franklin Lakes, NJ, USA) and apoptosis profiles were calculated using CellQuest software (V1.0.2; BD, Biosciences).

Cell invasion assay. Cell invasion assays were performed using Transwell inserts. The 786-O cells were treated with 5-Aza-dc as aforementioned. To prepare the Transwell inserts (Corning, Inc., Corning, NY, USA), the Matrigel (BD Biosciences) was dissolved at $4^{\circ} \mathrm{C}$ overnight, then diluted in RPMI-1640 medium without FBS. Subsequently, the Matrigel was added to pre-cooled Transwell inserts and incubated at $37^{\circ} \mathrm{C}$ for $2 \mathrm{~h}$ to solidify the Matrigel. Following this, the cells for each group were suspended in RPMI-1640 medium without serum. Subsequently, $1 \times 10^{4}$ cells were seeded in the upper Transwell chamber and incubated with RPMI-1640 medium without FBS for $24 \mathrm{~h}$. The cells on the inner surface were fixed in methanol and stained with $0.1 \%$ crystal violet at $37^{\circ} \mathrm{C}$ for $10 \mathrm{~min}$. Invasive cells were observed in six randomly selected fields, and the number of stained cells was counted at x200 magnification using an inverted microscope (Olympus Corporation, Tokyo, Japan).

Statistical analysis. Each experiment was repeated three times. All data were expressed as the mean \pm standard deviation of three independent experiments. All statistical calculations were performed using SPSS statistical software (version 20.0; IBM Corp., Armonk, NY, USA). The $\chi^{2}$ test or Fisher's exact test were used to analyze categorical variables, and the one-way analysis of variance or Wilcoxon rank sum test were used for analysis of continuous variables. $\mathrm{P}<0.05$ was considered to indicate a statistically significant difference.

\section{Results}

Aberrant methylation status of EN2 gene in cc-RCC samples and cell lines. To investigate whether the promoter of the EN2 gene in cc-RCC was hyper-methylated, MSP was performed in 40 pairs of cc-RCC tissues and matched adjacent non-malignant tissues. Aberrant methylation of EN2 gene was observed in 12/40 cc-RCC samples, but no methylation

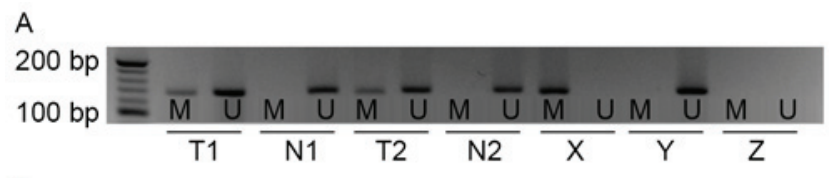

B

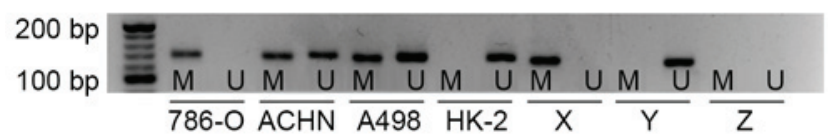

Figure 1. EN2 gene promoter methylation status determined in primary kidney tissues and cell lines. (A) EN2 gene promoter methylation in primary cc-RCC tissues and corresponding non-malignant kidney tissues as indicated by MSP analysis. (B) EN2 gene promoter methylation in cc-RCC cell lines: 786-O, ACHN, A498 and normal human proximal tubule epithelial cell line HK-2 as indicated by MSP analysis. cc-RCC, clear cell renal cell carcinoma; EN2, engrailed-2; MSP, methylation-specific polymerase chain reaction; $M$, presence of methylated DNA; U, presence of unmethylated DNA; T, primary cc-RCC tissue, T1, tissue sample 1 , T2, tissue sample 2 ; N, non-malignant kidney tissue; $\mathrm{X}$, methylated positive control; Y, unmethylated positive control; Z, negative control.

of the EN2 gene was observed in adjacent non-malignant tissues (Fig. 1A). This difference was considered to be significant $(\mathrm{P}<0.01)$. Subsequently, the methylation status of EN2 gene was evaluated in cc-RCC cell lines (786-O, ACHN and A498) and a normal human proximal tubule epithelial cell line (HK-2). Hyper-methylation of the EN2 gene was identified in all cc-RCC cell lines compared with HK-2. The results of the present study revealed complete EN2 promoter methylation in 786-O cells, partial methylation in ACHN and A498, and in HK-2 cells the EN2 promoter was unmethylated (Fig. 1B).

The association between the frequency of EN2 promoter methylation and the clinical pathological parameters of cc-RCC was analyzed. The frequency of EN2 promoter methylation was identified to be positively associated with histological grade $(\mathrm{P}=0.043)$ and tumor size $(\mathrm{P}=0.001)$ of cc-RCC (Table I). However, there was no statistical association identified between the frequency of EN2 promoter methylation and sex, age, tumor stage or lymph node metastasis (Table I).

Demethylation and re-expression of EN2 gene is induced following 5-Aza-dc treatment. Based on the MSP results of cc-RCC cell lines, the 786-O cell line was selected for further study. To validate whether downregulation of EN2 gene was associated with aberrant promoter methylation, the expression of EN2 gene was analyzed using RT-qPCR and western blot following treatment with different concentrations of 5-Aza-dc $(0,2.5,5,10$ and $20 \mu \mathrm{M})$ for 5 days. As determined using RT-qPCR, the mRNA expression of EN2 was increased in a concentration-dependent manner following treatment with 5-Aza-dc (Fig. 2A). The expression of EN2 in the $20 \mu \mathrm{M}$ group was 5.04-fold higher compared with the $0 \mu \mathrm{M}$ group $\left(2^{-\Delta \Delta C q}\right.$, $5.15 \pm 0.25$ vs. $1.02 \pm 0.21 ; \mathrm{P}<0.01)$. Consistent with the results of RT-qPCR, an increase in the levels of EN2 was observed following treatment with 5-Aza-dc (Fig. 2B). Furthermore, the methylation status of EN2 gene was decreased following treatment with 5-Aza-dc, in a dose-dependent manner (Fig. 2C). The results of the present study indicated that downregulation of the EN2 gene may be regulated by hyper-methylation of the EN2 promoter. 
Table I. Association between methylation status of EN2 with clinicopathological variables in patients with cc-RCC.

\begin{tabular}{|c|c|c|c|c|c|}
\hline \multirow[b]{2}{*}{ Variable } & \multirow{2}{*}{$\begin{array}{l}\text { Patients } \\
(\mathrm{n}=40)\end{array}$} & \multicolumn{2}{|c|}{$\begin{array}{l}\text { No. of patients with } \\
\text { EN2 DNA methylation }\end{array}$} & \multirow[b]{2}{*}{$\chi^{2}$} & \multirow[b]{2}{*}{ P-value ${ }^{a}$} \\
\hline & & $\mathrm{M}$ & $\mathrm{U}$ & & \\
\hline Tumor tissues & 40 & 12 & 28 & 14.118 & $<0.0001^{\mathrm{a}}$ \\
\hline Normal tissues & 40 & 0 & 40 & & \\
\hline \multicolumn{6}{|l|}{ Age, years } \\
\hline$\leq 60$ & 25 & 10 & 15 & 2.032 & 0.154 \\
\hline$>60$ & 15 & 2 & 13 & & \\
\hline \multicolumn{6}{|l|}{ Sex } \\
\hline Male & 26 & 5 & 21 & 2.768 & 0.096 \\
\hline Female & 14 & 7 & 7 & & \\
\hline \multicolumn{6}{|c|}{ Size of tumor, $\mathrm{cm}$} \\
\hline$\leq 4$ & 13 & 2 & 11 & 13.808 & $0.001^{\mathrm{a}}$ \\
\hline $4-7$ & 19 & 3 & 16 & & \\
\hline$>7$ & 8 & 7 & 1 & & \\
\hline \multicolumn{6}{|l|}{ TNM stage } \\
\hline $\mathrm{I} / \mathrm{II}$ & 34 & 9 & 25 & 0.458 & 0.499 \\
\hline III/IV & 6 & 3 & 3 & & \\
\hline \multicolumn{6}{|l|}{ Grade } \\
\hline G1 & 6 & 1 & 5 & 5.926 & $0.043^{\mathrm{a}}$ \\
\hline $\mathrm{G} 2$ & 22 & 4 & 18 & & \\
\hline G3 & 12 & 7 & 5 & & \\
\hline \multicolumn{6}{|c|}{ Lymph node metastasis } \\
\hline Yes & 5 & 3 & 2 & 0.798 & 0.372 \\
\hline No & 35 & 10 & 25 & & \\
\hline
\end{tabular}

${ }^{\mathrm{a}} \mathrm{P}<0.05$; EN2, engrailed-2; cc-RCC, clear cell renal cell carcinoma; M, methylated; U, unmethylated; TNM, tumor-node-metastasis.

Expression of EN2 induced by 5-Aza-d treatment inhibits cell proliferation and invasion. The proliferation of 786-O cells was analyzed following treatment with 5-Aza-dc (Fig. 3). The results of the MTT assay demonstrated that the proliferation rate of the cells significantly decreased with the increase in concentration of 5-Aza-dc compared with the untreated control after 1, 2, 3 and 5 days $(\mathrm{P}<0.05$; Fig. $3 \mathrm{~A})$. The proliferation rate of untreated control cells were on average 1.19, 1.37, 1.74 and 2.4-fold increased, compared with the $20 \mu \mathrm{M}$ groups at 1, 2, 3 and 5 days, respectively.

Cell apoptosis was subsequently analyzed using flow cytometry following treatment with 5 -Aza-dc for 5 days. The results suggested that the apoptotic rate increased in a dose-dependent manner (Fig. 3B and D). The mean apoptotic rates of for different concentrations of 5-Aza-dc were as follows: $0 \mu \mathrm{M}, 2.07 \pm 0.13 ; 2.5 \mu \mathrm{M}, 3.40 \pm 0.10 ; 5 \mu \mathrm{M}, 5.87 \pm 0.06 ; 10 \mu \mathrm{M}$, $7.50 \pm 0.10$; and $20 \mu \mathrm{M}, 17.17 \pm 0.85$. The apoptotic rates of cells treated with $2.5,5,10$ and $20 \mu \mathrm{M}$ were significantly increased compared with the untreated control ( $\mathrm{P}<0.05$; Fig. 3B).

Transwell assay was performed to analyze the effect of 5-Aza-dc treatment on cell invasion. Following treatment with 5 -Aza-dc for 5 days, the mean number of cells passing through the membrane for different concentrations were as follows: $0 \mu \mathrm{M}, 226.50 \pm 29.34 ; 2.5 \mu \mathrm{M}, 181.33 \pm 11.48 ; 5 \mu \mathrm{M}$,
$135.83 \pm 6.56 ; 10 \mu \mathrm{M}, 100.00 \pm 9.17$; and $20 \mu \mathrm{M}, 65.17 \pm 9.66$. The number of cells invaded in the 2.5, 5, 10 and $20 \mu \mathrm{M}$ 5-Aza-dc treatment groups were significantly increased compared with the untreated control $(\mathrm{P}<0.05$; Fig. $3 \mathrm{C}$ and $\mathrm{E})$.

\section{Discussion}

HOX genes act as transcription factors $(18,19)$. HOX genes can bind to specific DNA regions to activate or repress the expression of targeted genes, which are involved in a number of biological processes including cell apoptosis, motility and differentiation, angiogenesis and maintenance of organ function $(20,21)$. The EN2 gene belongs to the HOX family and serve a crucial function in the development of the nervous system at the human embryonic stage (22). In adults, aberrant expression of EN2 gene may be associated with tumorigenesis of a number of types of solid tumor (8,9,23-25). Morgan et al (25) observed EN2 was expressed in, and secreted by prostate cancer $(\mathrm{PCa})$ cell lines and tissues, but not by normal prostate tissue. In addition, it was reported that urinary EN2 may be a potential diagnostic biomarker for PCa, with a sensitivity of $66 \%$ and a specificity of $88.2 \%$ (25). These observations were consistent with the results of Marszałł et al (23). Furthermore, a previous study identified a statistical significant association 
A

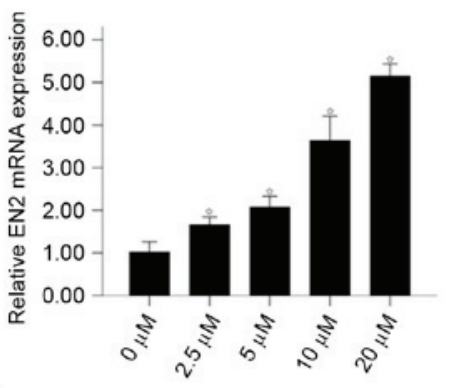

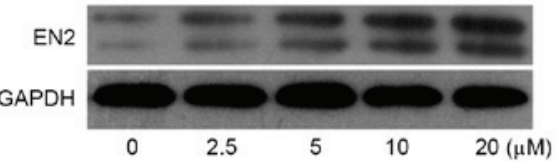

C

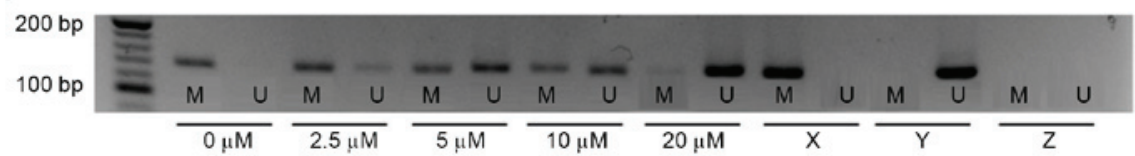

Figure 2. Effect of 5-Aza-dc treatment on the expression of EN2 and promoter methylation status in 786-O cells. 786-O cells were treated with various concentrations of 5-Aza-dc $(0,2.5,5,10$ or $20 \mu \mathrm{M})$ for 5 days. (A) The relative EN2 mRNA expression increased following treatment with 5-Aza-dc, analyzed using reverse transcription-quantitative polymerase chain reaction. (B) Effect of 5-Aza-dc treatment on EN2 protein expression as analyzed by western blotting. (C) Treatment with 5-Aza-dc induced EN2 gene promoter demethylation as analyzed using MSP. *P<0.05 vs. control (0 $\mu \mathrm{M}$ group). 5-Aza-dc, 5-aza-2-deoxycytidine; EN2, engrailed-2; MSP, methylation-specific polymerase chain reaction; M, presence of methylated DNA; U, presence of unmethylated DNA; X, methylated positive control; Y, unmethylated positive control; Z, negative control.
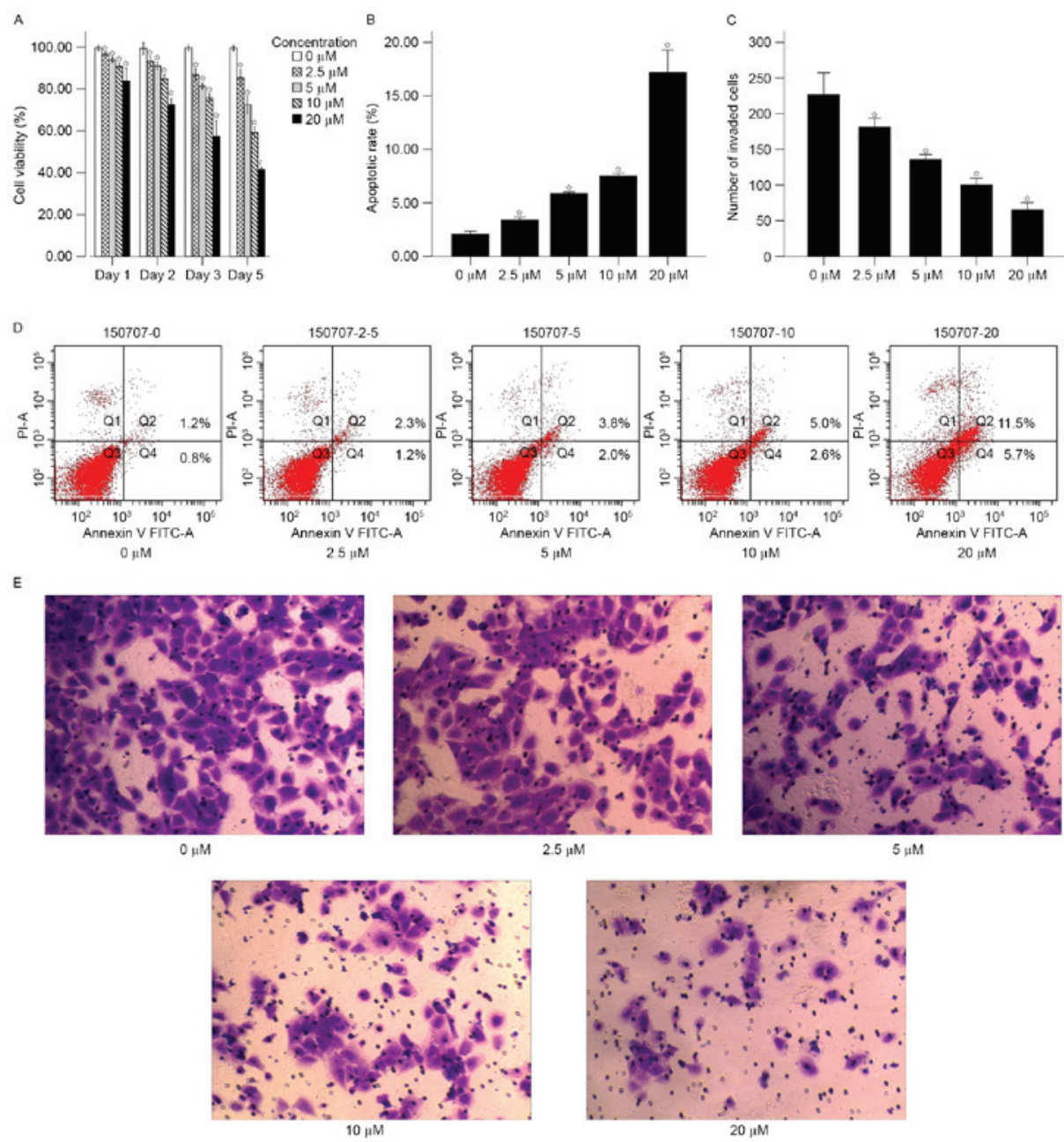

Figure 3. Determining the effects of re-expression of EN2 and 5-Aza-dc treatment on the apoptotic and invasive capacities of 786-O cells. (A) Effects of 5 -Aza-dc on the proliferation of 786-O cells analyzed using MTT assay. Cell viability was assessed at 1, 2, 3 and 5 days post-treatment with various concentrations of 5-Aza-dc $(0,2.5,5.10$ and $20 \mu \mathrm{M})$. (B) The effect of 5-Aza-dc treatment on apoptosis of 786-O cells as analyzed by fluorescence activated cell sorting assay. The cells were treated with various concentrations of 5-Aza-dc for 5 days. (C) Effect of 5-Aza-dc treatment on invasive capacity of 786-O cells as analyzed by Transwell assay. The cells were treated with various concentrations of 5-Aza-dc for 5 days. (D) The apoptosis assay was assessed in different groups that treated with various concentrations of 5-Aza-dc for 5 days. (E) Results of different groups transwell assay that treated with various concentrations of 5-Aza-dc for 5 days. Original magnification, $\mathrm{x} 200 .{ }^{*} \mathrm{P}<0.05$ vs. control ( $0 \mu \mathrm{M}$ group). EN2, engrailed-2; 5-Aza-dc, 5-aza-2-deoxycytidine; FITC, fluorescein isothiocyanate; PI, propidium iodide. 
between pre-surgical urinary EN2 levels and cancer volume in radical prostatectomy specimens (24). Additionally, the upregulation of EN2 gene was associated with progression in breast (8) and bladder (9) cancer.

A preliminary study by the present authors revealed that EN2 expression was downregulated in cc-RCC primary tissues and cell lines, whereas it was relatively highly expressed in normal proximal convoluted renal tubules and distal convoluted renal tubule epithelial cells (10). In another study by the present authors, EN2 expression was inhibited in HK-2 cells using lentivirus-mediated transfection, and overexpression of EN2 in 786-O cells was induced via plasmid transfection (26). Following the inhibition of the EN2 gene, proliferation and invasion of HK-2 cells were promoted. However the inhibition of the EN2 gene also resulted in a shortened cell cycle and inhibition of apoptosis. By contrast, overexpression of EN2 gene was able to promote apoptosis and reduce invasive ability and suppress proliferative ability of 786-O cells (26). These findings indicated that EN2 may have an anti-oncogenic function in cc-RCC. However, the mechanism leading to the downregulation of the EN2 gene in cc-RCC remains unknown.

There are several molecules that serve as two-way regulatory factors by either activating or repressing oncogenesis in different types of cancer (27-30). Most members of the HOX gene family are regarded as bidirectional regulation factors due to their tissue-specific expression and regulation (31). For example, HOXB13 was observed to be overexpressed in ovarian (32) and breast (33) cancer. Hwever, Jung et al (34) also reported that HOXB13 was downregulated in prostate cancer. Abate-Shen (35) proposed three mechanisms that drive the deregulation of HOX genes. One of these mechanisms was an epigenetic modification that leads to downregulation or silencing of HOX genes (35).

Hyper-methylation of EN2 has been identified in other diseases $(36,37)$. Abollo-Jiménez et al (36) identified that the EN2 gene promoter was methylated during the progression of chronic myelogenous leukemia to T-cell lineage-specific blast crisis. In addition, Lambert et al (37) reported that the EN2 gene was hyper-methylated in pilocytic astrocytoma (PA). The methylation status of the EN2 gene was associated with the location of PA (infratentorial vs. supratentorial) (37). Therefore, in the present study, it was hypothesized that aberrant methylation of the promoter may be the mechanism leading to the downregulation of the EN2 gene in cc-RCC.

To validate the aforementioned hypothesis, the methylation status of EN2 was analyzed in cc-RCC tissue specimens and cell lines, using MSP analysis in the present study. The results of the present study demonstrated that EN2 gene promoter was hyper-methylated in $12 / 40$ primary cc-RCC tissues and all tested cc-RCC cell lines, whereas none of the 40 adjacent non-malignant tissues revealed hyper-methylation. The results of the present study were similar to the findings reported by Slater et al (38). Slater et al observed that EN2 was hyper-methylated in chromophobe RCC (6/20) but not renal oncocytoma $(0 / 21)$. However, they did not investigate the function of EN2 methylation in chromophobe RCC (38). In the present study, the analysis of association between EN2 methylation and clinicopathological parameters indicated that EN2 methylation was significantly associated with increased malignant behavior in cc-RCC. Subsequently, 786-O cells, which revealed complete methylation, were selected to asses whether promoter methylation underlie the silencing of the EN2 gene in cc-RCC. Compared with untreated methylated 786-O cells, treatment of the cells with 5-Aza-dc increased the expression of EN2 mRNA and decreased the methylation of the EN2 promoter. These results suggested that promoter methylation was involved in the silencing of EN2 in cc-RCC. Following 5-Aza-dc treatment, EN2 was re-expressed and methylation status of the EN2 promoter was decreased. These results suggested that promoter methylation was involved in the silencing of EN2 gene in cc-RCC.

Following EN2 gene re-activation, proliferation and invasion of 786-O cells were markedly inhibited, whereas the apoptosis of 786-O cell was increased. It indicated that silencing of EN2 gene may promote the progression of cc-RCC.

However, there are several limitations of the present study that should be clarified. One of the limitations is the small sample size used. Therefore, additional studies with larger numbers of patients would be useful to demonstrate the use of EN2 as a biomarker. In addition, the present study was not able to determine the exact sites of $\mathrm{CpG}$ methylation of the EN2 gene promoter. In conclusion, the present study used tissue samples and cell lines to confirm that the EN2 gene promoter was hyper-methylated in cc-RCC, which may underlie the silencing of the EN2 gene.

\section{Acknowledgements}

The present study was supported by the National Natural Science Foundation of China (grant no. 81460386), the Natural Science Foundation of JiangXi Province (grant no. 20151BAB205014) and the Major Research Fund for the People's Livelihood of Guangzhou Science and Technology Plan (grant no. 2011Y-00003).

\section{References}

1. Siegel RL, Miller KD and Jemal A: Cancer statistics, 2015. CA Cancer J Clin 65: 5-29, 2015.

2. Vincenzi B, Santini D and Tonini G: Renal-cell carcinoma. N Engl J Med 354: 1095-1096, 2006.

3. Lam JS, Leppert JT, Belldegrun AS and Figlin RA: Novel approaches in the therapy of metastatic renal cell carcinoma. World J Urol 23: 202-212, 2005.

4. Volpe A and Patard JJ: Prognostic factors in renal cell carcinoma. World J Urol 28: 319-327, 2010.

5. Ljungberg B, Bensalah K, Canfield S, Dabestani S, Hofmann F, Hora M, Kuczyk MA, Lam T, Marconi L, Merseburger AS, et al: EAU guidelines on renal cell carcinoma: 2014 update. Eur Urol 67: 913-924, 2015

6. Simon HH, Thuret S and Alberi L: Midbrain dopaminergic neurons: Control of their cell fate by the engrailed transcription factors. Cell Tissue Res 318: 53-61, 2004.

7. Morgan R, Boxall A, Bhatt A, Bailey M, Hindley R, Langley S, Whitaker HC, Neal DE, Ismail M, Whitaker $\mathrm{H}$, et al: Engrailed-2 (En2): A highly specific urinary biomarker for the early diagnosis of prostate cancer. Clin Cancer Res 17: 1090-1098, 2011.

8. Martin NL, Saba-El-Leil MK, Sadekova S, Meloche S and Sauvageau G: EN2 is a candidate oncogene in human breast cancer. Oncogene 24: 6890-6901, 2005.

9. Morgan R, Bryan RT, Javed S, Launchbury F, Zeegers MP, Cheng KK, James ND, Wallace DM, Hurst CD, Ward DG, et al: Expression of Engrailed-2 (EN2) protein in bladder cancer and its potential utility as a urinary diagnostic biomarker. Eur J Cancer 49: 2214-2222, 2013. 
10. Lai CY, Pan B, Luo Y, Liang WB, Chen J, Ye DM, Guo JN, Li L and Su ZX: Engrailed-2 is down-regulated but also ectopically expressed in clear cell renal cell carcinoma. Mol Biol Rep 41: 3651-3657, 2014

11. Fang JC, Zhang $\mathrm{H}$ and Jin SF: Epigenetics and cervical cancer: From pathogenesis to therapy. Tumor Biol 35: 5083-5093, 2014.

12. Hauser S, Zahalka T, Fechner G, Muller SC and Ellinger J: Serum DNA hypermethylation in patients with kidney cancer: Results of a prospective study. Anticancer Res 33: 4651-4656, 2013.

13. Chmelarova M, Krepinska E, Spacek J, Laco J, Beranek M and Palicka V: Methylation in the p53 promoter in epithelial ovarian cancer. Clin Transl Oncol 15: 160-163, 2013.

14. Cancer Genome Atlas Research Network: Comprehensive molecular characterization of clear cell renal cell carcinoma. Nature 499: 43-49, 2013.

15. Guinan P, Sobin LH, Algaba F, Badellino F, Kameyama S, MacLennan G and Novick A: TNM staging of renal cell carcinoma: Workgroup No. 3. Union international contre le cancer (UICC) and the American joint committee on cancer (AJCC). Cancer 80: 992-993, 1997.

16. Japanease Urological Association: General Rule for Clinical and Pathological Studies on Renal Cell Carcinoma. 3rd edition. Kanehara Company, Tokyo, 1999.

17. Livak KJ and Schmittgen TD: Analysis of relative gene expression data using real-time quantitative PCR and the 2(-Delta Delta C(T)) method. Methods 25: 402-408, 2001.

18. Grier DG, Thompson A, Kwasniewska A, McGonigle GJ, Halliday HL and Lappin TR: The pathophysiology of HOX genes and their role in cancer. J Pathol 205: 154-171, 2005.

19. Lewis MT: Homeobox genes in mammary gland development and neoplasia. Breast Cancer Res 2: 158-169, 2000.

20. Kelly ZL, Michael A, Butler-Manuel S, Pandha HS and Morgan RG: HOX genes in ovarian cancer. J Ovarian Res 4: 16, 2011.

21. Veraksa A, Del Campo M and McGinnis W: Developmental patterning genes and their conserved functions: From model organisms to humans. Mol Genet Metab 69: 85-100, 2000.

22. Hanks M, Wurst W, Anson-Cartwright L, Auerbach AB and Joyner AL: Rescue of the En-1 mutant phenotype by replacement of En-1 with En-2. Science 269: 679-682, 1995.

23. Marszałł MP, Sroka W, Adamowski M, Słupski P, Jarzemski P, Siódmiak J and Odrowąż-Sypniewska G: Engrailed-2 protein as a potential urinary prostate cancer biomarker: A comparison study before and after digital rectal examination. Eur J Cancer Prev 24: 51-56, 2015.

24. Pandha H, Sorensen KD, Orntoft TF, Langley S, Hoyer S, Borre M and Morgan R: Urinary engrailed-2 (EN2) levels predict tumour volume in men undergoing radical prostatectomy for prostate cancer. BJU Int 110: E287-E292, 2012.

25. Morgan R, Boxall A, Bhatt A, Bailey M, Hindley R, Langley S, Whitaker HC, Neal DE, Ismail $\mathrm{M}$, Whitaker $\mathrm{H}$, et al: Engrailed-2 (EN2): A tumor specific urinary biomarker for the early diagnosis of prostate cancer. Clin Cancer Res 17: 1090-1098, 2011.
26. Lai CY, Xu Y, Yu GS, Wu X, Li YF, Pan B, Heng BL, Xue YJ and Su ZX: Engrailed-2 might play an anti-oncogenic role in clear-cell renal cell carcinoma. J Mol Histol 47: 229-237, 2016.

27. Farago M, Dominguez I, Landesman-Bollag E, Xu X, Rosner A Cardiff RD and Seldin DC: Kinase-inactive glycogen synthase kinase 3beta promotes Wnt signaling and mammary tumorigenesis. Cancer Res 65: 5792-5801, 2005.

28. Cao Q, Lu X and Feng YJ: Glycogen synthase kinase-3beta positively regulates the proliferation of human ovarian cancer cells. Cell Res 16: 671-677, 2006

29. Kang T, Wei Y, Honaker Y, Yamaguchi H, Appella E, Hung MC and Piwnica-Worms H: GSK-3 beta targets Cdc25A for ubiquitin-mediated proteolysis and GSK-3 beta inactivation correlates with Cdc25A overproduction in human cancers. Cancer Cell 13: 36-47, 2008.

30. Mai W, Kawakami K, Shakoori A, Kyo S, Miyashita K, Yokoi K, Jin M, Shimasaki T, Motoo Y and Minamoto T: Deregulated GSK3 3 beta\} sustains gastrointestinal cancer cells survival by modulating human telomerase reverse transcriptase and telomerase. Clin Cancer Res 15: 6810-6819, 2009.

31. Shah N and Sukumar S: The Hox genes and their roles in oncogenesis. Nat Rev Cancer 10: 361-371, 2010.

32. Miao J, Wang Z, Provencher H, Muir B, Dahiya S, Carney E, Leong CO, Sgroi DC and Orsulic S: HOXB13 promotes ovarian cancer progression. Proc Natl Acad Sci USA 104: 17093-17098, 2007.

33. Wang Z, Dahiya S, Provencher H, Muir B, Carney E, Coser K, Shioda T, Ma XJ and Sgroi DC: The prognostic biomarkers HOXB13, IL17BR, and CHDH are regulated by estrogen in breast cancer. Clin Cancer Res 13: 6327-6334, 2007.

34. Jung C, Kim RS, Zhang HJ, Lee SJ and Jeng MH: HOXB13 induces growth suppression of prostate cancer cells as a repressor of hormone-activated androgen receptor signaling. Cancer Res 64: 9185-9192, 2004

35. Abate-Shen C: Deregulated homeobox gene expression in cancer: Cause or consequence? Nat Rev Cancer 2: 777-785, 2002.

36. Abollo-Jiménez F, Campos-Sánchez E, Toboso-Navasa A, Vicente-Dueñas C, González-Herrero I, Alonso-Escudero E, González M, Segura V, Blanco O, Martínez-Climent JA, et al: Lineage-specific function of Engrailed-2 in the progression of chronic myelogenous leukemia to T-cell blast crisis. Cell Cycle 13: 1717-1726, 2014.

37. Lambert SR, Witt H, Hovestadt V, Zucknick M, Kool M, Pearson DM, Korshunov A, Ryzhova M, Ichimura K, Jabado N, et al: Differential expression and methylation of brain developmental genes define location-specific subsets of pilocytic astrocytoma. Acta Neuropathol 126: 291-301, 2013.

38. Slater AA, Alokail M, Gentle D, Yao M, Kovacs G, Maher ER and Latif F: DNA methylation profiling distinguishes histological subtypes of renal cell carcinoma. Epigenetics 8: 252-267, 2013. 